\title{
EXPERIENCIAS
}

\section{Preserving precariousness, queering debt}

\author{
Manteniendo la precariedad, \\ arruinando a través de la deuda ${ }^{1}$
}

Isabell Lorey (University of Kassel)

Artículo recibido: 26 de junio de 2018

Solicitud de revisión: 15 de noviembre de 2018

Artículo aceptado: 04 de febrero de 2019

Lorey, Isabell (2019). Preserving precariousness, queering debt. Recerca. Revista de Pensament i Análisi, 24(1), pp. 155-167.

\begin{abstract}
Precarisation means more than insecure jobs, more than the lack of security given by waged employment. By way of insecurity and danger it embraces the whole of existence, the body, modes of subjectivation. It is threat and coercion, even while it opens up new possibilities of living and working. Precarisation means living with the unforeseeable, with contingency. In this article I analyse how the new precarious living and working conditions and the privatisation of protection against precariousness are conditions of both a prospering financial capitalism and its concomitant debt economy. This economy is based on the expansion of productivity that involves less work, in the traditional sense, than subjectivation. A new subjectivity is needed to assume responsibility, to take on debt, and to internalise the risks both as guilt and as debt: a personality that is doubly indebted and responsible for oneself.
\end{abstract}

Key Words: precariousness, debt, subjectivation processes, financial capitalism.

\section{Resumen}

La precarización significa más que empleos inseguros, más que la falta de seguridad que proporciona el empleo asalariado. A través de la inseguridad y el peligro, la precarización abarca toda la existencia, el cuerpo, los modos de subjetivación. Es una amenaza y una forma

1 El presente texto presenta una versión revisada y ampliada de varios textos publicados anteriormente por la autora y de ahí su incorporación en la sección Experiencias.

This text is a revised and extended version of several texts by the author that were previously published, thus it's inclusion in the Experiences section. 
de coerción, aunque también abre nuevas posibilidades de vivir y trabajar. Precarización significa vivir con lo imprevisible, bajo la contingencia. En este artículo analizo cómo las nuevas condiciones de vida y de trabajo precarias y la privatización de la protección contra la precariedad son condiciones, tanto de un próspero capitalismo financiero, como de su concomitante economía de la deuda. Esta economía se basa en la expansión de la productividad, la cual implica más bien procesos de subjetivación que lo que hemos entendido por trabajo en el sentido tradicional. Se necesita una nueva subjetividad para asumir responsabilidades, para endeudarse e internalizar los riesgos como culpa y como deuda: una personalidad doblemente endeudada y responsable de sí misma.

Palabras clave: precariedad, deuda, procesos de subjetivación, capitalismo financiero.

\section{SUBJECTIVATING PRECARISATION AND PRODUCTION WITHOUT WAGE}

In neoliberal global capitalism not only the relation between capital and work is of central importance, but also that of time, flexibility, and measurability. Wages are sinking, while workload and hours spent working are on the rise. Working time no longer covers only tasks that are paid, but tends to encompass all social doing (Lorey, 2015a; Lorey \& Neundlinger, 2012). Work is becoming excessive and simultaneously negated as work that should be paid, especially when it comes to creative and cognitive work. The neoliberal ideology of «life-long learning», with its activating force, has extended the time of education beyond school and university degrees. The promise of learning something while at work, of gaining further qualifications, legitimises the non-payment or the extremely low payment of that work not only for the institution in which it is performed. It has also become normal for those who seek further qualification to become more and more financially indebted. The interlacing of knowledge and debt characterises central aspects of contemporary modes of production.

Knowledge, communication and creativity were only able to become productive thanks to a fundamental change in modes of production, that is, in how commodities and services are made, how work is organised and how capital accumulation occurs. This transformation can be observed from the 1970 onwards. With the crisis of Fordism, activities that were not traditionally understood as work, and were therefore not considered in terms of economic rationality, became increasingly relevant for the composition of the labour force. Forms of knowledge and activity have now gained significance were previously allocated not only to the cultural field, but above all to women in the reproductive sphere, such as affective and emotional 
labour (Precarias a la deriva, 2014). These are activities that are in demand today, primarily in the service sector: creative, affective and communicative activities, performed largely in precarious labour conditions: with temporary contracts, in part-time jobs.

When work becomes increasingly precarious, there is a tendency for the whole person to become labour power, body and intellectual capabilities included. The productivity of this form of work consists in the making of subjectivities and social relationships. Subjects and their capacities to socially interact become both the resource and the product of the new paradigm of political economy. Subjectivation and social relationships are made valuable in and through communication (Raunig, 2016). Connectedness with others is turned into economically exploitable relations of exchange. With this, both the strategic meaning of traditionally material and machinic means of production and the classic logic of investment in industrial capitalism lose significance. An array of their productive functions gets transferred onto the living, the social bodies of the labour force (Marazzi, 2011). In cognitive and communicative capitalism, these new means of production of machine-bodies are central cruxes for a specific dynamic of scarcity: rather than products, it is secure employment contracts that are in limited supply; precarisation is becoming the motor of productivity (Lorey, 2015b). Investments are made less in job creation and more in the expansion of digitalisation and increasing share values. More and more, new service-based production takes place without a wage or social security. The creative, communicative and affective capacities of workers, which tend to be formed outside of paid employment settings, get appropriated in companies and institutions as work that is usually unpaid (Lorey, 2015a).

Another important aspect of this scarcity is time. With the excessive extension of working time, the potential wealth of non-waged working time appears only as lack. When one's own personality and social relationships are made productive, it becomes increasingly more difficult to interrupt work as a refusal or strike. Individuals find themselves in a dynamic of disciplinary selfgoverning, which ensures not only productivity, but also obedience.

When sociality is made productive, it is not easy to grasp everyday social activity as work that must be paid. This contributes to the widespread belief that what is fun need not be paid. More and more people do not consider communication and the exchange of knowledge to be work. Self-precarisation is spreading like a virus (Lorey, 2006). 


\section{GOVERNING THROUGH PRECARISATION}

With the expansion of this increasingly de-waged mode of production based on communication, knowledge and affect, a form of governing has been established, now in Europe for over two decades, that does not legitimise itself by guaranteeing social protection and security for the majority of citizens, but is instead characterised by social insecurity and precarisation.

In my book State of Insecurity (2015a), I draw distinctions between three dimensions of the precarious. The first dimension, precariousness, denotes the dependence of every form of life on the care of and reproduction through others; on connectedness with others, which cannot be shaken off. Bodies remain precarious and need environments and institutions that provide security and support. The second dimension corresponds to the hierarchisation of this necessity. I call historically specific forms of insecurity -which are politically, economically, legally, and socially induced-precarity. These forms of insecurity are upheld by modes of governing, relations to the self and societal positionings that in turn shape the third dimension of the precarious, which, drawing on Michel Foucault, I call governmental precarisation.

Governing through precarisation means that the precarious are no longer solely those who can be marginalised to the peripheries of society. Due to the individualising restructuring of the social welfare state, the deregulation of the labour market and the expansion of precarious employment conditions, we currently find ourselves in a process of the normalisation of precarisation, which also affects larger portions of the middle class. In this normalisation process, precarisation has become a political and economic instrument of governing. At the same time, people continue to be legally, economically and socially marginalised and excluded through structural inequality, through precarity, which means that they are less protected than others or that protection is altogether denied them (Butler, 2009). This becomes apparent in the various western democracies with simultaneously occurring processes of economic and financial border elimination, on the one hand, and border creation to ward off global migration, on the other. Legal status and mobility are being hierarchised in order to facilitate extreme forms of exploitation. Through the dismantling and restructuring of collective security systems, individualised risk management is demanded according to societal positioning along the scale of precarity, yet this takes shape in very different ways, depending on gender, class, «race», origin or legal status. 
Social security, and therefore also social reproduction, are being increasingly de-collectivised; they are again being privatised, but this time handed over to the self-responsibility of the individual and capitalised. As a result, more and more people are only able to fund retirement provisions, healthcare and education by taking on debts. At the same time, the productivity of the self and of sociality in low-wage or unpaid positions leads directly to indebtedness. De-collectivisation and its accompanying individualisation of risk, self-management and self-responsibility, as well as the capitalisation of reproduction, are the central anchoring points in the neoliberal regime of precarisation for an economy of guilt and debt.

\section{GUILT AND DEBT}

Precarious living and working conditions and the privatisation of protection against precariousness are conditions of both a prospering financial capitalism and its concomitant debt economy. This economy is based on the expansion of productivity that involves less work, in the traditional sense, than subjectivation (Lazzarato, 2012). A subjective figure is needed to assume responsibility, to take on debt and to internalise the risks both as guilt and as debt: a personality that is doubly indebted and responsible for oneself. This personality plays a decisive role in enabling and stabilising neoliberal governing through precarisation and insecurity, for there is no longer an outside of debt. Everybody is indebted in one or another way: «If it is not individual debt, it is public debt that weighs, literally, on every individual's life, since every individual must take responsibility for it». As Maurizio Lazzarato (2012) reminds us, Friedrich Nietzsche, Karl Marx and also Gilles Deleuze and Félix Guattari have expressly linked the debt economy with morality, that is, with specific modes of subjectivation. In the Christian genealogy, becoming indebted cannot be separated from burdening oneself with guilt. According to Nietzsche, incurring debt results in guilt through the promise to repay creditors. The indebted person promises to continuously behave in such a way that they are able to give back what was given to them, so that they can pay back their debts. In the debt economy, this financial exchange constitutes subjectivation. The obligation to pay back debt corresponds to that disciplinary self-governing that ensures not only subjectivising and social productivity, but also compliance. To place one's 
behaviour at the service of repaying debt means to place life and sociality at the service of debt and to make oneself even more governable.

To understand the governmental intertwining of time, precarisation and debt, it is important to bear in mind that precarisation means dealing with the unforeseeable, with contingency, acting without being able to predict what the near or distant future will bring. It is precisely this ability to deal with contingency that is exploited by the loan contract, preventing any agency that might start something new or refuse to work under the given conditions. The financial promise of the repayment of debt must go on, even if it requires something decidedly paradoxical of the indebted person: in their precarisation they must estimate something inestimable, namely, the future. «[T] $]_{0}$ view the future as the present and anticipate it», as formulated by Nietzsche (2006: 36), means not only controlling the future in the present, but also through selfgoverning to make precarisation and the precarised person calculable in the incalculability of their life and to hold them under control - yet doing so primarily on behalf of the creditor.

In self-precarisation, however, this paradox of calculating the incalculable is reversed, the temporality of debt is phantasmatically inverted: by investing the self in what is supposedly one's 'own' future, the doubly indebted personality consciously accepts precarisation in the present. The fantasy of shaping the future means accepting precarisation in the present. For the illusion of a predictable and better time-to-come, self-precarisation appears to be a necessary investment, above all amongst the north-western European middle classes. What is abandoned in this projection of a future is the agency that might start something new in the present.

Starting something new, taking action, as Marx already pointed out, requires forces that emerge from sociality, from relatedness with others, from precariousness: trust in oneself, in others and thus in the world (Lazzarato, 2012 $^{2}$. And it is precisely this trust -this ethical relationship- that gets exploited by credit and indebtedness.

2 Marx also argues this in his essay, 'Comments on James Mill', see: https://www.marxists.org/archive/marx/works/1844/james-mill/ 


\section{INSTITUTIONS THAT SPREAD}

As the figure of the indebted person spreads, public spending for art and education institutions is increasingly reduced, making their funding more and more dependent on private donors and fundraising. The exchange relation that comes with this manifests in the «modulation of creativity» (Raunig, 2013: 109), the framework in which all areas of the institution are evaluated: from attendance numbers to publication rankings and online clicks. When productivity develops primarily through communication and the making and maintaining of relationships, this productivity must be not only constantly on display, but also counted and thereby made measurable. In this way, a supposed equivalent is constructed against which funding can be assessed, and which must be permanently produced and productive. Individuals become subservient to this end, including their relational capacities. In this logic of exchange, the production of the social extends the concrete place of the institution and thus the place of work.

It encompasses not only the social relationships to donors, but also to artists, neighbours and between members of staff. This capitalisation of sociality also encompasses the countless places and networks that extend beyond the institutional space. The institution spreads in the socialities of those working. Future donors, artists and attendees could be found anywhere. In line with the capitalisation of knowledge, affect and communication, and also of the whole person and social relationships, the individuals constantly make the institution: at every exhibition launch, at every party, in many «private» everyday situations, through electronic communication from home. The socialities of the whole staff become part of institutionalisation; the institution is lived such that it can be capitalised, each employee is, with all of their social capacities, responsible for the perpetual process of institutionalisation, which does not escape the logic of repaying the loan (Lorey, 2018a). Working time becomes living time, each worker, with their affects and communicative capacities, remains permanently indebted to the donors. Along with this comes the constantly increasing acceleration of production, the calculation of sociality according to efficiency criteria, the lack of time to do something other than produce countable sums of loan repayment.

If capital exploits social activities and therefore life itself, however, this does not mean that, in turn, resistance is no longer possible, no other living practices, no other modes of passing time. As the debt and finance economy 
increasingly enjoys access to social activities through measuring and evaluation, a break with the concomitant partitioning of time becomes necessary. We need time, a time of break, one in which the general mobilisation can be stalled, a time that suspends the time of debt and exploitation. An idle time (Lazzarato, 2015). This break in time would need to be more than the subjective refusal of work. Another mode of living time is required, one that takes back the social wealth that is commonly produced. «To re-transform money into available time» as Lazzarato writes, «to transform wealth into possibility, not only struggle but also new processes of subjectivation are needed» (Lazzarato, 2015: 251). A common exodus; a common refusal to be governed in this way and simultaneously subjectivised as capitalisable; a refusal to economically instrumentalise affects and relationships. This would also be an exodus from all forms of masculinist economy.

\section{PRESERVING PRECARIOUSNESS, QUEERING DEBT}

In his considerations on debt, gift and credit, Jacques Derrida points out that there are phenomena that remove themselves from exchange, from the dynamic of giving and taking, and therefore from the debt economy, which can neither be possessed nor repaid, and which also cannot be remitted.

To give time, the day, or life is to give nothing, nothing determinate, even if it is to give the giving of any possible giving, even if it gives the condition of giving (Derrida, 1992: $54)$.

Infinite debts for which no forgiveness is possible. Care and protection that make survival/life possible can be excessive gifts that suspend the economic calculus of debt, depart from the economy of debts and allow the impossible to begin (Derrida, 1992).

In a similar way, in the 1970 os Hélène Cixous already proposed to break through the masculinist gift economy and the asymmetry of the debt relation. To give a gift that expects no return, and which cannot be given back, means for Cixous:

Making a gift of departure», departing, taking off, leaving. Such a gift without return allows breaks, «parts», partings, separations... from this we break with the return-to-self, 
with the specular relations ruling the coherence, the identification, of the individual (Cixous, 1981: 53).

To suspend identity, return and thus also the indebted autonomy allows for leaps in time, writes Cixous: giving up self-referentiality, the reference back to oneself, and instead: «departing», beginning without origin. This corresponds to the capacity to lose control and let go: to wander around, to risk the incalculable, the unforeseeable, that which cannot be anticipated. The gift that breaks with the debt economy makes possible a becoming-precarious in the present, without credit into and for the future, that which credit does not allow: to begin something new.

Giving without return, without credit, without future, necessitates another understanding of the present: away from the moment, which linearly moors past and future, a moment that is only ever rushed through, which is imagined without duration, on the way to the process, to the expansion, to an expanded present as a temporality of becoming. In the normalisation of precarisation it becomes apparent precisely in the crisis of the debt economy that there is no future, and at the same time, through this, a new present simultaneously opens in which people care about how they want to live now (Desideri \& Harney, 2013).

Becoming-precarious in the present, without credit in the future, is no individual undertaking. It is always a becoming-precarious together with others. A common capacity to depart in the present and begin something new. This implies an understanding of the present that I call «presentist» (Lorey, 2017 and 2014). To become-precarious in the now, to take off in a leap of time; Benjamin (1940) says, to prepare for the leap into the open sky: presentist becoming-precarious. Coming from the precarious, the presentist does not devalue or defend commonly shared precariousness and the connectedness with others resulting from it. The presentist-precarious preserves precariousness, actualises it in the expanded present.

"Credit is a means of privatisation and debts a means of socialisation», write Stefano Harney and Fred Moten.

And credit can only expand by means of debt. But debt is social and credit is asocial. Debt is mutual. Credit runs only one way. But debt runs in every direction, scatters, escapes, seeks refuge (Harney \& Moten, 2013: 61). 
These bad debts are endlessly distributed debts, which for social reasons, for reasons of being_with and not for economic or moral reasons, cannot be repaid: «debt without creditor, the black debt, the queer debt», write Harney and Moten (2013: 61), because they flee identity, are without referencing, without autonomy, full of affections. To practise bad debts corresponds to the capacity to be affected by others, by people and things: to be open, vulnerable, precarious (Lorey, 2018b). Becoming-precarious as the capacity of becoming affected.

These bad debts are not based on the idea of the autonomous, legally capable individual and the predetermination of the future. They break through the white, masculinist logic of debts and of the identity of debtors, they move as they expand differences, for everyone owes something else. Taking bad, social debts as the point of departure leads to a complicity without borders of belonging, to the principle of association. Not to scarcity and lack, for the elimination of which debts are accumulated and things must be made better in the future, but rather to the abundance of social wealth, to excess in the now.

To do something other than work, other than extending financialisation into socialities, other than amortising and repaying debt or having one's debt forgiven, it is necessary to transgress the economic measure of equivalence, the paradigm of calculation, measurement, counting, ranking, appraisal. To (once again) realise the incalculability of a social economy of existence is a prerequisite to an exuberant giving without caring about measurability. Becoming-precarious means being open for an organisation in/of the present that disobeys the linear relation to the future and of which it is not yet known to where it leads and what it brings, an organisation in the present for which it is necessary to now take the time.

\section{REFERENCES}

Benjamin, Walter (1940). On the Concept of History. Retrieved from: https://www.marxists.org/reference/archive/benjamin/1940/histor y.htm [Consulted 16 May, 2018]

Butler, Judith (2009). Frames of War. When Is Life Grievable?. London/New York: Verso. 
Cixous, Hélène (1981). Castration or Decapitation? Signs. Journal of Women in Culture and Society, 7.1, 41-55.

Derrida, Jacques (1992). Given Time: I. Counterfeit Money. Chicago: University of Chicago Press.

Desideri, Valentina \& Harney, Stefano (2013). Fate Work: a conversation, Ephemera: Theory and Politics in Organisation, 13(1), 159-176.

Dowling, Emma (2016). Love's Labour's Cost: The Political Economy of Intimacy, February 2016. Retrieved from: http://www.versobooks.com/blogs/2499-love-s-labour-s-cost-thepolitical-economy-of-intimacy [Consulted 15 May, 2018]

Harne, Stephano \& Moten, Fred (2013) The Undercommons. Fugitive Planning \& Black Study, Wivenhoe/New York/Port Watson: Minor Compositions.

Lazzarato, Maurizio (2012). The Making of the Indebted Man. An Essay of the Neoliberal Condition. Los Angeles: Semiotext(e).

Lazzarato, Maurizio (2015). Governing by Debt. Los Angeles: Semiotext(e).

Lorey, Isabell (2006). Governmentality and Self-Precarization: On the Normalization of Culture Producers. In Rosenblatt, Lisa. Transversal: Machines and Subjectivation. Retrieved from: http://transversal.at/transversal/1106/lorey/en [Consulted 15 May, 2018]

Lorey, Isabell (2014). Presentist Democracy. Exodus and Tiger's Leap,

Transversal Texts. Retrieved from:

http://transversal.at/blog/Presentist-Democracy [Consulted 17

May, 2018]

Lorey, Isabell (2015a). State of Insecurity. Government of the Precarious. London: Verso.

Lorey, Isabell (2015b). Autonomy and Precarization. In Dockx, Nico \& Gielen, Pascal (Eds.). Mobile Autonomy. Exercises in Artists' SelfOrganisation, Amsterdam: Valiz, pp. 39-52 
Lorey, Isabell (2017). Presentist Democracy. Reconceptualizing the Present. In Latimer, Quinn \& Szymczykds, Adam (Eds.). documenta 14. Munich: Reader, pp. 169-202.

Lorey, Isabell (2018a). Presentist Democracy: Destituent Breaks, Instituent Practices, Constituent Process. In Hlavajova, Maria (Ed.). Cambridge/MA, London: MIT Press (forthcoming).

Lorey, Isabell (2018b). The Power of the Presentist-Performative. On Current Democracy Movements. In Vujanovic, Ana \& Piazza, Livia Andrea (Eds.): A Live Gathering: Performance and Politics, (forthcoming)

Lorey, Isabell \& Neundlinger, Klaus (2012). Kognitiver Kapitalismus. Von der Ökonomie zur Ökonomik des Wissens. Einleitung. In Lorey, Isabell \& Neundlinger, Klaus (Eds.). Kognitiver Kapitalismus, Wien: Turia + Kant, pp. 7-55.

Marazzi, Christian (2011). The Violence of Finance Capitalism. Los Angeles: Semiotext(e).

Nietzsche, Friedrich (2006). On the Genealogy of Morality and Other Writings. Cambridge: Cambridge University Press.

Precarias a la deriva (2014). Was ist dein Streik? - Militante Streifzüge durch die Kreisläufe der Prekarität. Vienna: Transversal Texts.

Raunig, Gerald (2013). Factories of Knowledge. Industries of Creativity. Los Angeles: Semiotext(e).

Raunig, Gerald (2016). Dividuum. Machinic Capitalism and Molecular Revolution. Vol. 1. Los Angeles: Semiotext(e). 